\title{
Different memory $T$ cell phenotypes are elicited by Ad5 and rare adenoviruses
}

\author{
P Penaloza ${ }^{1 *}$, E Borducchi ${ }^{1}$, A McNally ${ }^{1}$, N Simmons ${ }^{1}$, J Teigler ${ }^{1}$, N Provine ${ }^{1}$, W Tan², R Ahmed ${ }^{2}$, DH Barouch ${ }^{1}$ \\ From AIDS Vaccine 2012 \\ Boston, MA, USA. 9-12 September 2012
}

\section{Background}

The anamnestic potential of memory $\mathrm{T}$ cells are pivotal components of the adaptive immune response. Analyzing memory $\mathrm{T}$ cells elicited by different vaccine vectors is crucial for the identification of novel vaccine modalities against HIV.

\section{Methods}

6-8 week old C57BL6 mice were used for these experiments. Mice were immunized intramuscularly with $10^{\wedge} 10$ VP in PBS. The different adenoviral vaccines (Ad5, Ad26, Ad35, Ad48) expressed the glycoprotein (GP) derived from lymphocytic choriomeningitis virus (LCMV). For challenge studies, the mice were infected with $2 \times 10^{\wedge} 6 \mathrm{PFU}$ of LCMV Cl-13 intravenously. Early and late CD4 and CD8 $\mathrm{T}$ cell recall was measured by flow cytometry. Viral control was assessed by standard plaque assay on VERO cells.

\section{Results}

We have compared $\mathrm{T}$ cell memory phenotypes and immune protection elicited by common adenoviruses serotype 5 (Ad5) versus rare adenoviruses serotypes (Ad26, Ad35, and Ad48). For these comparative studies, we immunized mice with non-replicating adenovirus vectors expressing the lymphocytic choriomeningitis virus (LCMV) GP, and challenged with chronic LCMV Cl-13. Our comparative data show that Ad5-GP generates an increased magnitude of LCMV GP-specific CD8 T cell responses (compared to that generated by rare adenoviruses). However, GP-specific CD8 T cells elicited by Ad5-GP immunization express inhibitory PD-1, and produce reduced amounts of cytokines, suggesting qualitative defects in memory CD8 $\mathrm{T}$ cells. This unexpected expression of PD-1 may also reflect antigen-persistence of Ad5.

Beth Israel Deaconess Medical Center, Boston, MA, USA

Full list of author information is available at the end of the article

\section{Conclusion}

Memory $\mathrm{T}$ cells elicited by rare adenovirus-based vaccines results in greater $\mathrm{T}$ cell recall potential after viral challenge, and higher functionality compared to vaccination with Ad5. These data suggest that alternative serotype Ad vectors may offer substantial benefits over Ad5 as vaccine vectors in eliciting optimal $\mathrm{T}$ cell memory to chronic viruses such as $\mathrm{HIV}, \mathrm{HBV}$ or $\mathrm{HCV}$.

\section{Author details}

${ }^{1}$ Beth Israel Deaconess Medical Center, Boston, MA, USA. ${ }^{2}$ Emory University, Atlanta, GA, USA.

Published: 13 September 2012

\section{doi:10.1186/1742-4690-9-S2-P246}

Cite this article as: Penaloza et al:: Different memory T cell phenotypes are elicited by Ad5 and rare adenoviruses. Retrovirology 2012 9(Suppl 2): P246.
Submit your next manuscript to BioMed Central and take full advantage of:

- Convenient online submission

- Thorough peer review

- No space constraints or color figure charges

- Immediate publication on acceptance

- Inclusion in PubMed, CAS, Scopus and Google Scholar

- Research which is freely available for redistribution
C Bïomed Central 